\title{
Ichthyosis: A Harbinger of Lymphoma
}

\author{
Kundan Mishra, ${ }^{1}$ Aditya Jandial, ${ }^{1}$ Kirti Gupta, ${ }^{2}$ Gaurav Prakash, ${ }^{1}$ Pankaj Malhotra
}

${ }^{1}$ Department of Medicine, Postgraduate Institute of Medical Education and Research, Chandigarh, India ${ }^{2}$ Department of Pathology, Postgraduate Institute of Medical Education and Research, Chandigarh, India

\section{Correspondence to}

Dr Kundan Mishra, mishrak20@rediffmail.com

Accepted 16 March 2018

\section{Check for updates}

To cite: Mishra K, Jandial A, Gupta K, et al. BMJ Case Rep Published Online First: [please include Day Month Year]. doi:10.1136/bcr-2018224229

\section{DESCRIPTION}

A 60 -year-old, previously healthy woman presented with patchy skin colour change and dryness for 3 months duration. She also gave a history of recurrent boils requiring local and oral antibiotics. On examination, patchy hyperpigmented skin with scaly appearance was apparent along with features of healed and active infection (figure 1). She also had multiple, firm, lymph nodes (largest $2 \mathrm{~cm}$ ) in the bilateral axillae. On evaluation, haemoglobin was $115 \mathrm{~g} / \mathrm{L}$, white blood cells $7.8 \times 10^{9} / \mathrm{L}$, platelets $248 \times 10^{9} / \mathrm{L}$; peripheral blood smear was normal. Representative skin biopsy showed loss of granular layer characteristic of ichthyosis (figure 2). Right axillary lymph node excision biopsy and immunohistochemistry confirmed the diagnosis of T-cell non-Hodgkin's lymphoma (not otherwise specified). HIV ELISA, thyroid function tests and coeliac serology were inconclusive. She was treated with cyclophosphamide, doxorubicin, vincristine and prednisolone chemotherapy along with moisturisers (urea-based), regular skin cleansing and salty water bath. After six cycles of chemotherapy, she achieved complete remission with partial improvement in ichthyosis.

Acquired ichthyosis is an uncommon dermatosis characterised by disrupted skin cornification. Herein, dry and thickened skin confers the characteristic 'fish-like' appearance and significant morbidity in the form of itching, heat intolerance, recurrent infections and restricted joint mobility.

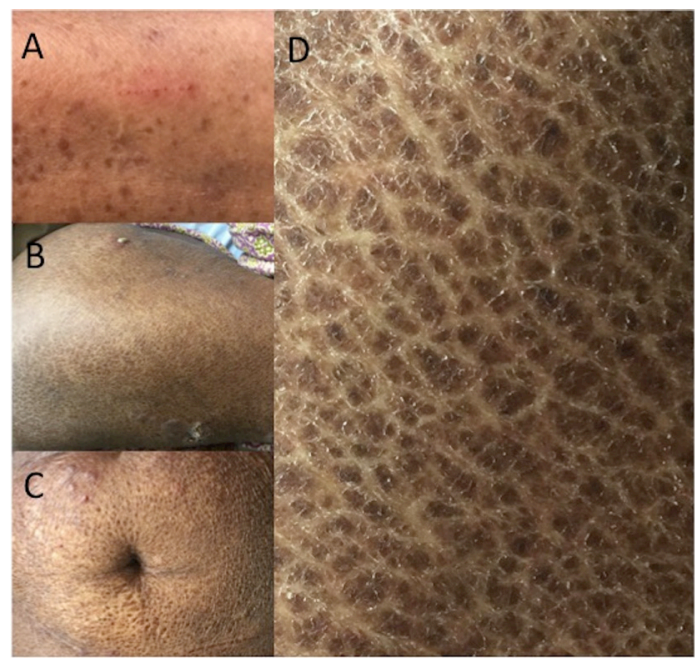

Figure 1 (A) Clinical photograph showing scaly, hyperpigmented lesions over upper limb with a linear lesion resulting from scratching; (B) ichthyosis and associated healed lesions over lower limb along with a pustule; (C) ichthyosis along with healed lesions over abdomen; (D) typical hyperpigmented scaly lesions over back giving rise to 'fish scale' appearance.

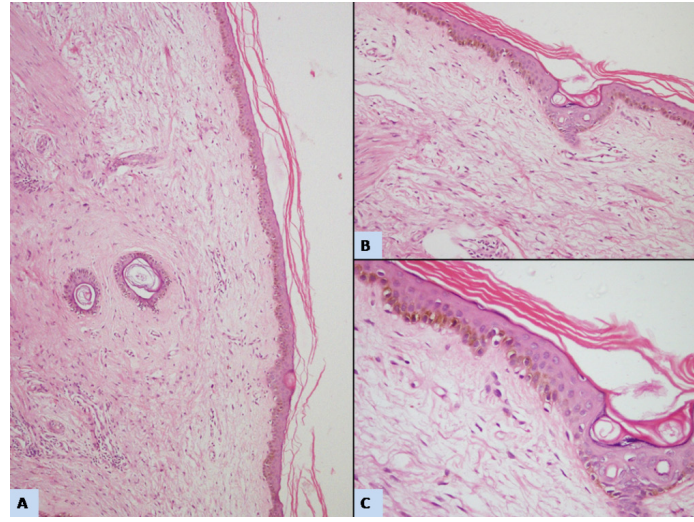

Figure 2 (A) Low magnification of skin biopsy showing epidermis and dermis (H\&E $\times 100)$; (B) epidermis demonstrates loss of normal basket weave pattern (H\&E $\times 200)$; (C) high magnification demonstrates loss of granular layer within the epidermis, characteristic of ichthyosis $(H \& E \times 400)$.

Besides neoplastic disorders (Hodgkin's lymphoma, anaplastic large cell lymphoma, mycosis fungoides, POEMS (polyneuropathy, organomegaly, endocrinopathy, monoclonal protein, skin changes) syndrome, etc), it is known to be associated with malnutrition, infections (HIV, Human T-lymphotropic virus (HTLV)), hypothyroidism, coeliac disease, sarcoidosis, graft-versus-host disease and drug intake (hydroxyurea, allopurinol, vemurafenib, etc). ${ }^{12}$ Hence, it is crucial to emphasise that new-onset ichthyosis in any adult patient should be actively evaluated to unveil the underlying cause. Management consists of treatment of the underlying cause together with measures directed at reducing skin dryness and scaling. ${ }^{3} \mathrm{~T}$-cell non-Hodgkin's lymphoma (NOS) presenting with ichthyosis has rarely been described in literature; probably due to short survival. In the index case, occurrence of unapparent additional factors (eg, nutritional deficiency, autoimmune disorder, etc) shall explain incomplete resolution of ichthyosis.

\section{Learning points}

Ichthyosis has a characteristic morphology and pathological features (as depicted in figures 1 and 2).

- New-onset ichthyosis in an adult necessitates detailed work-up to find out the underlying secondary cause.

- Ichthyosis per se can cause significant morbidity that can be difficult to manage.

Contributors All authors contributed to the management of the patient. KM and AJ prepared the manuscript, which was read and accepted by all the authors. 


\section{Images in...}

Funding The authors have not declared a specific grant for this research from any funding agency in the public, commercial or not-for-profit sectors.

Competing interests None declared.

\section{Patient consent Obtained.}

Provenance and peer review Not commissioned; externally peer reviewed.

(c) BMJ Publishing Group Ltd (unless otherwise stated in the text of the article) 2018. All rights reserved. No commercial use is permitted unless otherwise expressly granted.

\section{REFERENCES}

1 Word AP, Cayce R, Pandya AG. Beware of underlying malignancy: acquired ichthyosis. Am J Med 2014;127:202-4.

2 Errichetti E, Stinco G, Pegolo E, et al. Acquired ichthyosis during acitretin therapy for psoriasis vulgaris. J Eur Acad Dermatol Venereol 2016:30:181-2.

3 Tanita K, Fujimura T, Sato Y, et al. Successful treatment of primary cutaneous peripheral t-cell lymphoma presenting acquired ichthyosis with oral bexarotene monotherapy. Case Rep Oncol 2017;10:328-32.

Copyright 2018 BMJ Publishing Group. All rights reserved. For permission to reuse any of this content visit http://group.bmj.com/group/rights-licensing/permissions.

BMJ Case Report Fellows may re-use this article for personal use and teaching without any further permission.

Become a Fellow of BMJ Case Reports today and you can:

- Submit as many cases as you like

- Enjoy fast sympathetic peer review and rapid publication of accepted articles

- Access all the published articles

Re-use any of the published material for personal use and teaching without further permission

For information on Institutional Fellowships contact consortiasales@bmjgroup.com

Visit casereports.bmj.com for more articles like this and to become a Fellow 